Job spoke the truth about God (Job 42:7-8)

Krüger, Thomas

DOI: https://doi.org/10.1515/9783110428148-006

Posted at the Zurich Open Repository and Archive, University of Zurich ZORA URL: https://doi.org/10.5167/uzh-146767

Book Section

Published Version

Originally published at:

Krüger, Thomas (2018). Job spoke the truth about God (Job 42:7-8). In: Jones, Scott C; Yoder, Christine Roy. "When the morning stars sang" : essays in honor of Choon Leong Seow on the occasion of his sixty-fifth birthday. Berlin: De Gruyter, 71-80.

DOI: https://doi.org/10.1515/9783110428148-006 


\section{The Problem ${ }^{1}$}

At the end of the book of Job, Yнwh says to Eliphaz the Temanite:

I am incensed at you and your two friends, for you have not spoken the truth about me as did my servant Job. Now take seven bulls and seven rams and go to my servant Job and sacrifice a burnt offering for yourselves. And let Job, my servant, pray for you; for to him I will show favor and not treat you vilely, since you have not spoken the truth about me as did my servant Job. (Job 42:7-8) ${ }^{2}$

The statement that Job has spoken the truth about YHwH comes as a bit of a surprise after Job's final speech in 42:1-6, in which he qualified-if not revoked-all his former comments: "Indeed, I spoke without understanding of things beyond me, which I did not know” (42:3). Is Job’s final self-criticism in this verse wrong in the eyes of Үнwн? Was Job right when he said that God "destroys the blameless and the guilty" and mocks the plight of the innocent "when suddenly a scourge brings death" (9:22-23)? Is it true that God does not take action against evil and does not care about the victims of injustice (Job 21; 24)? Has God "disarmed and humbled" Job, "regarded him as clay," and made him "like dust and ashes" (30:11, 19) without cause?

Modern commentators have often found it difficult to imagine that this was the opinion of the authors or editors of the book of Job. In 1895 Duncan Macdonald wrote:

Either there is here the most absolute contradiction or there is the most tremendous irony on the part of the author. There is no escape from this dilemma; either we have some structural confusion that annihilates sense, or the indictment of the rule of the universe is crowned by a plea of guilty from its Ruler.... It is true that exegetes make the most ingenious attempts to smooth out this contradiction, but what will not exegetes attempt? ${ }^{3}$

1 I would like to thank Sarah Shectman and Scott C. Jones for editing my English.

2 All citations from the Hebrew Bible are direct quotations or adaptations from the NJPS, unless otherwise noted.

3 Duncan B. Macdonald, “The Original Form of the Legend of Job," JBL 14 (1895): 63-71, here 66.

DOI 10.1515/9783110428148-006 
In this essay, I argue that one should take the final words of God in the book of Job seriously: Job did speak the truth about God, and God's acknowledgment of that fact means, as Macdonald stated, that Job's "indictment of the rule of the universe is crowned by a plea of guilty from its Ruler."

\section{Common Exegetical Solutions}

Macdonald holds that Job 42:7-8 can only be understood as the literary residue of an earlier version of the book of Job in which Job

had taken God's part, while his friends had followed more or less implicitly the course of Job's wife in our prologue.... In this form of the story he is patient throughout. He endures the trials of the Satan, the querulousness of his wife,... the compassion of his friends, how expressed we cannot now know, and we can only conjecture that it must have contained murmurs against God; he endures all and in the end receives his reward. He has spoken of God that which is right. ${ }^{4}$

Even if one agrees with this explanation, the question of how to understand YHwH's statement that Job has spoken the truth about him in its present context remains open-unless one follows Macdonald in thinking that the book of Job from ch. 27 on is "a chaos" consisting of "fragments dating from different periods in his [the book's author's] development."5

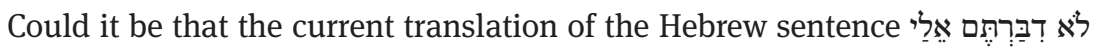

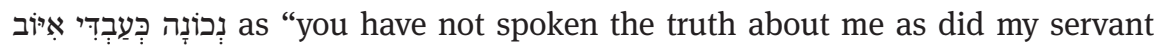
Job" or the like is simply wrong? Manfred Oeming suggests that the proclamation should instead be translated, "ihr habt nicht recht $z u$ mir geredet wie mein Knecht Hiob." ${ }^{6}$ According to Oeming, God does not say that what Job has spoken about him was true, but rather that it was right that Job spoke to God, even if Job accused God of injustice and mercilessness. Indeed, in chs. 3-27 (and in

4 Macdonald, "The Original Form," 66-67. For other commentators who share this view, see Hans-Peter Müller, Das Hiobproblem (3d ed.; Darmstadt: Wissenschaftliche Buchgesellschaft, 1995), 36-48; Choon Leong Seow, Job 1-21: Interpretation and Commentary (Illuminations; Grand Rapids, MI: Eerdmans, 2013), 28-29.

5 Macdonald, "The Original Form," 69.

6 Manfred Oeming, "Ihr habt nicht recht von mir geredet wie mein Knecht Hiob," EvT 60 (2000): 103-116, here 113 ["you have not spoken rightly to me as did my servant Job"]. Cf. Dale Patrick, "Job’s Address to God," ZAW 91 (1979): 268-282, esp. 269; Kenneth N. Ngwa, The Hermeneutics of the 'Happy' Ending in Job 42:7-17 (BZAW 354; Berlin: de Gruyter, 2005), 11-12. 
chs. 32-37) the friends never address God directly, whereas Job does so several times. In particular, they never pray for Job as Job does for them in 42:8.

Oeming argues that the preposition אֶל after אֶר (not) אמר (qal) usually (and in the book of Job always) means "(to speak) to somebody" (not about somebody or something). ${ }^{7}$ But in the Hebrew Bible, אֶל are often confused, ${ }^{8}$ and in a considerable number of instances אל "about, concerning" instead of "to, toward." Most notably, even if one agrees with Oeming's interpretation of the preposition אל in Job 42:7-8, one must reckon with the fact that YнwH claims not only that Job has spoken to him (unlike his friends), but also that Job has spoken "the truth" (נְככוֹנָה) ${ }^{10}$ to him. Since Job did not hold back from saying to YнwH what he had already said about God to his friends, Oeming's interpretation of Job 42:7-8 does not altogether solve the difficulties that passage poses. One is still left with the question: How does Job speak "truth" to God?

Some exegetes assume that in Job 42:7-8 YнwH refers not to Job's speeches in Job 3-31 but to his final statement in 42:1-6, which revokes Job's earlier comments. ${ }^{11}$ However, the beginning of 42:7-8 ("after Yнwн had spoken these words to Job, Yнwн said to Eliphaz the Temanite ...”) connects these lines to the end of Job 41 and virtually ignores 42:1-6, which would be odd if 42:7-8 were meant to make specific reference to Job’s statement in 42:1-6. Others think that נְכנוֹנה in 42:7-8 does not mean "the truth" or "what is true" but something like "honestly" or "with understandable motives" or even "constructively." But these appear to be ad hoc hypotheses. ${ }^{12}$

7 Oeming, "Ihr habt nicht recht von mir geredet," 113.

8 In the book of Job, compare the BHS apparatus for 1:8; 2:5; 15:13, 25, 26; 34:28. In 2 Chr 32:19, דבר (pֶe in one sentence, both times meaning "(to speak) about."

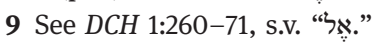

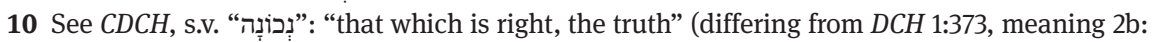
"correctly, certainly"). For a defense of the traditional translation, "the truth," compare Edward L. Greenstein, review of Duck Woo Nam, Talking about God: Job 42:7-9 and the Nature of God in the Book of Job, RBL 7 (2004): 3; cited 29 April 2016; online: http://www.bookreviews.org/pdf/ 3195_3573.pdf; also Ngwa, Hermeneutics, 13.

11 See Georg Fohrer, Das Buch Hiob (KAT 16; Gütersloh: Gütersloher Verlagshaus Gerd Mohn, 1963), 539: "Eigentlich enthalten nur die Hiobworte in 40,4-5; 42,2-6 das 'Wahre' über Gott" ["only Job's words in 40:4-5; 42:2-6 contain 'what is true' about God"]. In Fohrer's view, this is true for the present edition of the book of Job. In an earlier edition, 42:7-8 referred to a dialogue between Job and his three friends that has been replaced by ch. 3-31 (and 32-37).

12 Cf. the literature cited in n. 10 above. 


\section{An Attempt to take Job 42:7-8 Seriously}

In Job 42:7-8, YHwH draws a contrast between what Job said about him and what Job's friends said about him. It therefore seems likely that YHWH refers here to what Job and his friends said in the poetic dialogue (Job 3-31). ${ }^{13}$ Job 42:7-8 clearly states that what the friends said about God is wrong. Thus it is wrong, among other things, that (1) God regularly rewards or punishes humans according to their good or bad conduct; (2) no human being can be righteous and innocent before God; (3) people who are suffering may not accuse God; (4) traditional knowledge about God and the world has more weight than one's own experience; and (5) humans are not able to make true statements about God and the world because of their limited knowledge. ${ }^{14}$

Conversely, Job 42:7-8 states that what Job said about God is correct. But doesn't Job appear in some instances to say the same thing as his friends? So, for example, in 24:13-24 and 27:13-23 what Job says about the fate of the wicked is virtually the same as what the three friends said in their preceding speeches. This has led some exegetes to conclude that the present shape of Job $22-28$ is a result of (accidental or intentional) editorial confusion or supplementation. ${ }^{15}$ But these passages are perhaps to be taken ironically (cf. 24:25 and 27:7) as meaning the opposite of what they are saying. Job 24:13-24 may also be interpreted not as a description of how things are but as a description of how things should be. ${ }^{16}$ Similarly, Job 27:7 may be a clue that the following is to be read in an optative sense: "May my enemy be as the wicked; my assailant, as the wrongdoer." Here Job may have both his friends and God in view as enemies and assailants (cf. 13:24, 19:11, 30:21).

Job also appears to agree with his friends that no human being can be completely righteous and innocent before God (14:4, 16-17). But if so, Job argues, God should not meticulously punish every single wrongdoing but forgive

13 Among others, see Seow, Job 1-21, 87-92; Edward L. Greenstein, "Truth or Theodicy? Speaking Truth to Power in the Book of Job,” PSB 27 (2006): 238-58, here 256-58; Norman C. Habel, The Book of Job (OTL; Philadelphia: Westminster, 1985), 583- 84; Marvin H. Pope, Job (AB 15; Garden City, NY: Doubleday, 1965), 290.

14 These basic theological opinions of Job's friends are expounded in their first speeches (on 1-3, cf. Job 4-5; on 4, cf. Job 8; and on 5, cf. Job 11) and repeated and elaborated in the following rounds of talks.

15 See Seow, Job 1-21, 29-30.

16 Compare the Old Greek translation of vv. 18-19 and 20: "May their earthly portion be cursed, and may their plants on earth appear withered ... may what he did be paid back to him, and may every unjust person be crushed like an incurable tree” (NETS). 
human sins and overlook minor errors (7:17-21). Moreover, Job holds on to his innocence in the sense that his disaster cannot be reasonably understood as an adequate punishment for his wrongdoing $(13: 18,23)$. In so doing, Job clearly contradicts his friends. ${ }^{17}$

Like his friends, Job states that humans cannot argue with God; however, in Job's view this is not because God is always in the right, as Bildad says in 8:3, but because God is so mighty that no one can put him on trial (9:2-20) or sit in judgment against him (9:32-33).

Job also agrees with his friends that humans only have limited knowledge about God and the world $(23: 8-9 ; 28)$. But in Job's view this does not compromise his ability to judge whether God is treating him justly or unfairly or whether the world is just. Whereas Job's friends are convinced that traditional knowledge about God and the world has more weight than one's own experience (8:8-10), Job insists that his experiences are valuable sources of knowledge (6:30, 12:11, 13:1).

When God acknowledges in 42:7-8 that Job has spoken the truth about him, the main points in view appear to be the following: (1) Every statement about God is perspectival. (2) God is ambivalent and sometimes self-contradictory. (3) God is not fair (at least not always). (4) When humans are confronted with God's injustice, they may appeal to God against God. I now treat each of these in turn.

\subsection{Every Statement about God is Perspectival ${ }^{18}$}

Job's friends talk about God in the third person. They speak of God as if they were standing on the sidelines as uninvolved onlookers. When they do refer to their own experiences (in the first person), it is only to confirm traditional and “objective” knowledge (cf., e.g., 5:27; 15:17-19). Job’s speeches, however, challenge his friends' “objective” knowledge (15:4). They respond by attempting to devalue and invalidate Job's arguments, drawing on the traditional and collective knowledge of past generations (8:8-10).

Job is well aware of the differences between his own point of view and that of his friends (16:4). He insists on his own experience yet admits that his words

17 In their first speeches, Job’s friends appear to be convinced of his innocence (cf. 4:6; 8:6; less clearly, 11:14). But as the dialogue goes on, they are more and more convinced of Job's guilt (cf. 15:5-6).

18 See Carol A. Newsom, The Book of Job: A Contest of Moral Imaginations (Oxford: Oxford University Press, 2003). 
may be rash because he is in his distress (6:2-5). Unlike his friends, Job does not urge them to adopt his perspective, but he asks them to accept that what he says about God is true to his experience and thus not without reason (21:2-5). So they should tolerate his talk, even if they disagree $(6: 14) .{ }^{19}$

\subsection{God is Ambivalent and Sometimes Self-Contradictory ${ }^{20}$}

Job's friends are convinced that God is always and unambiguously just and fair in his interactions with humans (see, e.g., Job 8). If his actions sometimes seem to be opaque or unfair, this is only because God is so great that humans cannot grasp his motives and deliberations (see, e.g., Job 11). In that case, humans ought to humble themselves before God (see, e.g., Job 5). To doubt God's justice is out of the question (cf. 8:3). God's actions are sometimes constructive and sometimes destructive, but they are always fair (see, e.g., 5:10-16).

In contrast, Job insists that God acts destructively or constructively ${ }^{21}$ without any understandable reason (see, e.g., 9:3-9, 17). ${ }^{22}$ Eventually God destroys what he has carefully created (see, e.g., 10:8-19). God blessed Job and protected him, his household, and his possessions (1:10; cf. Job 29), but there came a day when God stripped Job of everything he had and struck him with deadly illness (Job 1-2; cf. Job 30). God requires humans to fear him and to shun evil (28:28; cf. 1:8; 2:3), but God also destroys the blameless and the guilty without distinction (9:22). God is thus ambivalent and even self-contradictory.

\subsection{God is Not Fair (At Least Not Always)}

Statements such as those found in 9:22-23 no doubt make it difficult for some interpreters to accept YHwH's judgment that Job's God-talk was “truth.” There

19 That every statement about God is perspectival is confirmed and underlined by the composition of the book of Job. Not only do Job and his friends have different points of view, but so do the narrator and God. One of the unsettling effects of this literary device is that readers of the book are left to wonder why God discloses to Job that he was testing him and whether God thinks that Job has passed the test.

20 See Katherine J. Dell, The Book of Job as Sceptical Literature (BZAW 197; Berlin: de Gruyter, 1991).

21 Accordingly, God shows in his speeches in Job 38-41 that he likes order (38:4-38) as well as chaos (represented by Behemoth and Leviathan in 40:15-41:26).

22 Compare God's own confession to having mistreated Job without reason (2:3). 
Job says that God "destroys the blameless and the guilty. When suddenly a scourge brings death, He mocks as the innocent fail." It is indeed difficult to see why God would ultimately agree with such statements. However, in the speeches in Job 38-41 YнwH does not show the slightest interest in human beings who are suffering, exploited, and oppressed. And in the prologue (Job 1-2), YнwH does not shy away from allowing countless humans and animals to be killed, just to determine whether Job fears God only because God cares for him. Thus the dire picture of God in some of Job's speeches is in fact compatible with the views of God exhibited by the narrator of Job 1-2 and the poet of Job $38-41$. Indeed, this gloomy picture of God is brightened little by God's final confession in 42:7-8 (cf. 31:33-34).

In 2:3, YHwH says to the Satan: "You have incited me against [Job] to destroy him for no good reason." In 42:7-8, YнwH frankly admits that he is in danger of

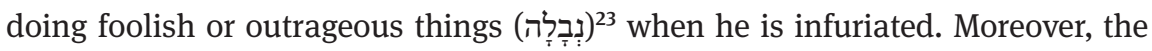
double restitution of Job's property in 42:12 can be understood as an admission of guilt on the part of YHWH and as an attempt to propitiate Job (cf. Exod 22:2-3). In view of these strikingly self-critical statements by Yнwн, it is not completely inconceivable that in 42:7-8 "the indictment of the rule of the universe is crowned by a plea of guilty from its Ruler," as Macdonald argued. ${ }^{24}$

Moreover, this plea of "guilty" from the ruler of the universe may be the real happy ending of the book of Job. It is obvious to Job that this world is not just (Job 21; 24). Its creator and ruler by all appearances only occasionally steps in against injustice, if at all (38:12-15). But God also never claims to be fair. Nevertheless, God does at least occasionally listen to human laments, complaints, or even accusations and change his course of action, as in the case of Job. (Sadly, after Job's restoration neither God nor Job appears to care for the multitudes of suffering, exploited, and oppressed humans whose lot Job bewailed so impressively in Job 24.)

23 According to $\mathrm{CDCH}$, נְבדלָ means "sacrilege, outrage, serious disorderly conduct, rather than

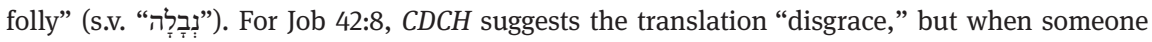
does נִבְ with/to others, the "disgrace" is on the side of the acting subject, not on the side of the objects. Cf. Ngwa Hermeneutics, 16-18.

24 Macdonald, "The Original Form," 66. 


\subsection{Appealing to God against God ${ }^{25}$}

Not only does Job state that God is ambivalent and unfair (at least sometimes), but he also hopes that God can be moved to change his mind and (re-)establish justice. Job's friends express the same hope, at least in their first speeches (cf. e.g., 4:6-7; 5:8-26). But they are reluctant to argue with God and to address their reproaches to him (cf. 5:1-7). Instead, they try to defend God and answer for him $(13: 7-8 ; 36: 2)$.

Job, however, wants to argue with God. In the course of the dialogue with his friends, Job is at first highly skeptical about the possibility of bringing God before the court (9:32-33). But he grows increasingly confident that God (or some heavenly being) will eventually vindicate him $(16: 19-21 ; 19: 25-27)$ or at least answer him (31:35-37). Thus Job not only complains about God but also tries to influence God to change his mind and behavior.

Job's efforts are at least partially successful. In 42:7-8, Yнwн finally accepts Job's verdict that he is a wicked wrongdoer and eventually confesses that he mistreated Job and wronged him. As a result, Yнwн "restored Job’s fortunes" and "blessed the latter years of Job's life more than the former" (42:10, 12). Apparently such an attitude change cannot be expected regularly, as Job's friends had suggested (cf. 5:8-26; 8:5-22); it is exceptional and unreliable. Nevertheless, it may be something of a silver lining at the end of the book of Job: God may not be fair, but sometimes humans who confront him as Job did can move God to intercede against injustice. And sometimes, as in 42:7-8, God even asks humans to step in to prevent him from acting foolishly and vilely when he is incensed. ${ }^{26}$

\section{Conclusion}

If the above considerations are correct, the picture of God drawn by the book of Job is similar to divine depictions in the most prominent "Joban" literary works of the ancient Near East. Thus the Poem of the Righteous Sufferer, Ludlul bèl nemeqi, ${ }^{27}$ begins with a hymn on the ambivalence of Marduk:

25 According to Jörg Jeremias, this is one of the theological highlights of the book of Job (Theologie des Alten Testaments [Grundrisse zum Alten Testament 6; Göttingen: Vandenhoeck \& Ruprecht, 2015], 472-73).

26 Remarkably, after Job had already desisted from arguing with God in 40:3-5, Yнwн again incited him to continue the dispute (40:6-7).

27 Benjamin R. Foster, Before the Muses: An Anthology of Akkadian Literature (3d ed.; Bethesda: CDL Press, 2005), 392-409. 
Furious in the night, growing calm in the day:

Whose anger, like a raging tempest, is a desolation,

But whose breeze is sweet as the breath of morn. (I 4-6) ${ }^{28}$

Human beings and their opinions are similarly inconstant:

Suddenly one is downcast, in a trice full of cheer,

One moment he sings in exaltation, in a trice he groans like a professional mourner....

Starving, they become like corpses,

Full, they would rival their gods.

In good times, they speak of scaling heaven,

When it goes badly, they complain of going down to hell. (II $40-47)^{29}$

What appears to be true depends on one's perspective and personal circumstances.

Toward the end of the so-called Babylonian Theodicy, ${ }^{30}$ the friend of the sufferer blames the main creator gods for human injustice:

Enlil [Narru], king of the gods, who created teeming humankind,

Majestic Ea [Zulummar], who pinched off their clay,

The queen who fashioned them, mistress Mami,

Gave twisted words to the human race,

They endowed them in perpetuity with lies and falsehood. $(276-80)^{31}$

Nevertheless, the only way out for humans is to ask the gods for help, as the sufferer does at the end of the poem:

May the god who has cast me off grant help,

May the goddess who has [forsaken me] take pity,

The shepherd Shamash will past[ure] people as a god should. $(295-297)^{32}$

The depiction of God in the book of Job is different from the depiction of God as a good and fair ruler of the world, which is more prominent elsewhere in the Hebrew Bible (cf. e.g., Ps 145). But the idea that God is ambivalent, causing good and bad alike (Job 2:10, 42:11), is not completely foreign to the Hebrew Bible (e.g., Isa 45:6-7: "I am YHwH and there is none else, I form light and create

28 Ibid., 394.

29 Ibid., 399.

30 Ibid., 914-22.

31 Ibid., 921.

32 Ibid., 922. 
darkness, I make weal and create woe-I Yнwн do all these things"; and Amos 3:6: "Can misfortune come to a town if YHwH has not caused it?"). ${ }^{33}$

The depiction of God in the book of Job is approximated in the New Testament's comparison of God to an unjust judge moved to carry out his duty by the persistent pleas of a widow (Luke 18:2-5). ${ }^{34}$ The insight that God is not fair (at least not in the sense of retributive fairness or justice ${ }^{35}$ ) is not completely foreign to Christian theology. ${ }^{36}$ Arguing with God is an important part of Jewish tradition. ${ }^{37}$ The book of Job is an impressive encouragement to struggle with an unfair God, and an expression of hope that God will not ignore human arguments or even indictments. ${ }^{38}$ Instead of defending God's fairness, as Job's "counsellors" do, people should help those who are in distress, like Job's relatives and friends, who plainly act against God and thereby move YHWH to change his mind:

All [Job's] brothers and sisters and all his former friends came to him and had a meal with him in his house. They consoled and comforted him for all the misfortune that YHWH had brought upon him. Each gave him one kesitah and each one gold ring. Thus YHwH blessed the latter years of Job’s life more than the former. (Job 42:11-12)

33 A passionate plea against this view can be found in Sir 39:16-35: "all the works of the Lord are (very) good" (vv. 16 and 33, NRSV).

34 According to François Bovon (Luke 2 [Hermeneia; Minneapolis: Fortress Press, 2013], 532), Luke 18:2-5 "may go back substantially to the historical Jesus (although it is true that some of the wording results from successive rereadings)." In the original parable, the relationship between the judge and the widow appears to be a model for the relationship between God and humans, whereas the present context stresses the difference between the unjust judge and God. 35 For Paul, “'the righteousness of God,' ... means God's saving activity (Rom. 1.18), characteristically seen in justification by his grace through faith (Rom. 3.21-6). Indeed one of the reasons why the apostle is often held to be quoting a pre-Pauline formula in the last passage is that in $\mathrm{v}$. 25 God's righteousness can be held to mean God's justice in a strictly judicial sense and not his saving activity" (John Ziesler, "Righteousness," in The Oxford Companion to the Bible [ed. Bruce M. Metzger and Michael D. Coogan; Oxford: Oxford University Press, 1993], 655-56, here 655). 36 See Andreas Beck, Gott ist nicht gut und nicht gerecht: Zum Gottesbild der Gegenwart (Düsseldorf: Patmos, 2008).

37 See Anson Laytner, Arguing with God: A Jewish Tradition (Lanham, MD: Rowman \& Littlefield, 1990).

38 See David R. Blumenthal, Facing the Abusing God: A Theology of Protest (Louisville: Westminster John Knox, 1993). 